\title{
The speciation and bioavailability of mercury in sediments of Haihe River, China
}

\author{
Jian-bo Shi ${ }^{\mathrm{a}}$, Li-na Liang ${ }^{\mathrm{a}}$, Gui-bin Jiang ${ }^{\mathrm{a}, *}$, Xing-long Jin ${ }^{\mathrm{a}, \mathrm{b}}$ \\ ${ }^{a}$ Key Laboratory of Environmental Chemistry and Ecotoxicology, Research Center for Eco-Environmental Sciences, Chinese Academy of Sciences, \\ P.O. Box 2871, Beijing 100085, China \\ ${ }^{\mathrm{b}}$ Environmental Science and Engineering College, Nankai University, Tianjin 300071, China
}

Received 3 June 2004; accepted 24 August 2004

Available online 3 October 2004

\begin{abstract}
Twenty-one sediment samples in 11 sites along the Haihe River and Dagu Drainage River, Tianjin, China, were analyzed to investigate the pollution status and bioavailability of mercury $(\mathrm{Hg})$. The results showed that the Haihe River was slightly polluted with $\mathrm{Hg}$ when flowing through Tianjin city. On the contrary, the sediments collected from Dagu Drainage River, an important drainage river in Tianjin, were found to have very high $\mathrm{Hg}$ concentrations and the highest concentration reached $8779.1 \mathrm{ng} \mathrm{g}^{-1}$ (dry weight). The methylmercury $(\mathrm{MeHg})$ concentrations accounted for $0.1-2.4 \%$ (average: $0.9 \%$ ) of total mercury $(\mathrm{HgT}$ ) and were strongly influenced by $\operatorname{HgT}(r=0.91, p=0.99, n=20)$ and total organic carbon (TOC; $r=0.76, p=0.99, n=20)$ contents in sediments. Moreover, a five-step sequential selective extraction (SSE) procedure was used to study the bioavailability of $\mathrm{Hg}$ in sediments. The mercury in sediments existed mainly as element $\mathrm{Hg}$ and mercury sulfide, which accounted for $46.5 \%$ and $39.0 \%$ of $\mathrm{HgT}$, respectively. The percentage of exchangeable $\mathrm{Hg}$ (defined as water soluble $\mathrm{Hg}$ plus 'human stomach acid' soluble $\mathrm{Hg}$ ) was only $0.1-4.6 \%$. The distribution of exchangeable $\mathrm{Hg}$ showed an obvious difference to that of $\mathrm{HgT}$, indicating that the $\mathrm{HgT}$ concentrations were absolutely insufficient to evaluate the risk of $\mathrm{Hg}$ in sediments.
\end{abstract}

(C) 2004 Elsevier Ltd. All rights reserved.

Keywords: Speciation; Sequential extraction; Methylmercury; Mercury; Sediment

\section{Introduction}

In aquatic system, sediment is an important sink and source of mercury $(\mathrm{Hg})$ and is also considered as the main production site of methylmercury $(\mathrm{MeHg})$. Now, the concentration of total mercury $(\mathrm{HgT})$ is not by far the most important because various chemical species of mercury behave distinctly, thereby affecting its biogeochemical behavior and toxicity to organisms (Cai et al., 1997). As the most toxic mercury species, $\mathrm{MeHg}$ is neurotoxic and can cause blockage of binding sites of enzymes, interfere protein synthesis and impede thymidine incorporation into DNA

\footnotetext{
* Corresponding author. Fax: +86 1062849179 .

E-mail address: gbjiang@mail.rcees.ac.cn (G. Jiang).
}

(Thayer, 1984). Furthermore, MeHg could be accumulated in the animal and human food chain more easily than the inorganic forms; thus, it was given particular concern all the time.

On the other hand, the toxicity and bioavailability of mercury in sediment also depend on its interaction with the native matrix. As we know, $\mathrm{Hg}$ has an extremely high affinity for organic matter and S-containing ligands (Wallschläger et al., 1996; Hintelmann et al., 1995). These complexes are often stable and thus this fraction of $\mathrm{Hg}$ has lower mobility and toxicity. On the other side, the watersoluble $\mathrm{Hg}$ has higher risk because it can easily enter the aquatic system and accumulate in organism. Moreover, changes in environmental conditions, such as acidification or redox potential, can cause $\mathrm{Hg}$ mobilization from the solid to the liquid phase and favour the contamination of 
surrounding waters. Therefore, it is indispensable to identify the main binding sites and phase associations of $\mathrm{Hg}$ when assessing its risk in sediment.

Tianjin city, with a population of 9.16 million, is an important industrial base in China. The total amounts of industrial and domestic effluents discharged in 1999 were $4.42 \times 109$ and $3.57 \times 109 \mathrm{~m}^{3}$, respectively (Zhang, 2002). Haihe River is a central river flowing through the Tianjin city and gathering many other streams before entering Bohai Sea at last. It was polluted by the inpouring of industrial, domestic and agricultural effluents in recent years, which exerted a great disadvantageous effect to the ecosystem in it (Qin et al., 1998; Zhen et al., 1999). It was reported that the concentrations of biochemical oxygen demand (BOD; Liu et al., 2001), chemical oxygen demand (COD; Liu et al., 2001) and dissolved oxygen (DO; Zhao et al., 1996) were very high. Mercury as a very toxic element is still widely used in manufacture of chlorine, pesticides, fungicides and production of electrical goods, paper, batteries and so on. As many kinds of these factories have been built in Tianjin city, the discharge of industrial effluents might be a potential pollution source of $\mathrm{Hg}$ to Haihe River.

The aim of this work was to investigate the pollution status and bioavailability of $\mathrm{Hg}$ in Haihe River sediments. The HgT was determined by cold vapor atomic fluorescence spectrometry (CVAFS) and the $\mathrm{MeHg}$ in sediment was analyzed by HPLC-AFS. A five-step sequential selective extraction (SSE) method was used for studying the mobility and bioavailability of $\mathrm{Hg}$ in sediments. The distributions of $\mathrm{HgT}, \mathrm{MeHg}$ and different fractions of $\mathrm{Hg}$ were investigated. Moreover, the relationships among
$\mathrm{HgT}, \mathrm{MeHg}$ and total organic carbon (TOC) were also studied.

\section{Materials and methods}

\subsection{Instrumentation}

AF-610A atomic fluorescence spectrometer (Beijing Raleigh Analytical Instrument, China) was used for total mercury determination. The laboratory-established HPLC (P680 HPLC Pump, DIONEX, USA) and AFS (AF610A, Beijing Raleigh Analytical Instrument) hyphenation system was as described previously (Liang et al., 2003a,b). A ZORBAX ODS column $(4.6 \times 150 \mathrm{~mm}, 5$ $\mu \mathrm{m}$, Agilent Technologies, USA) was utilized to separate $\mathrm{MeHg}$ in samples. Total organic carbon concentrations were determined using Apollo 9000 TOC analyzer (Tekmar-Dohrmann, USA). The stainless steel grab used for sampling was purchased from Wildlife Supply (Michigan, USA).

\subsection{Reagents and standards}

Stock solutions of standard mercury chloride $\left(\mathrm{HgCl}_{2}\right.$, Merck) and methylmercury chloride $\left(\mathrm{CH}_{3} \mathrm{HgCl}\right.$, Merck; 1 $\mathrm{mg} \mathrm{mL}{ }^{-1}$ as $\mathrm{Hg}$ ) were prepared by dissolving appropriate amounts of which in $5 \%(\mathrm{v} / \mathrm{v}) \mathrm{HNO}_{3}$ and methanol, respectively. The mercury working solutions were obtained by dilution with $10 \%(\mathrm{v} / \mathrm{v}) \mathrm{HNO}_{3}$ or methanol and prepared daily before use. All solutions were stored at $4{ }^{\circ} \mathrm{C}$.

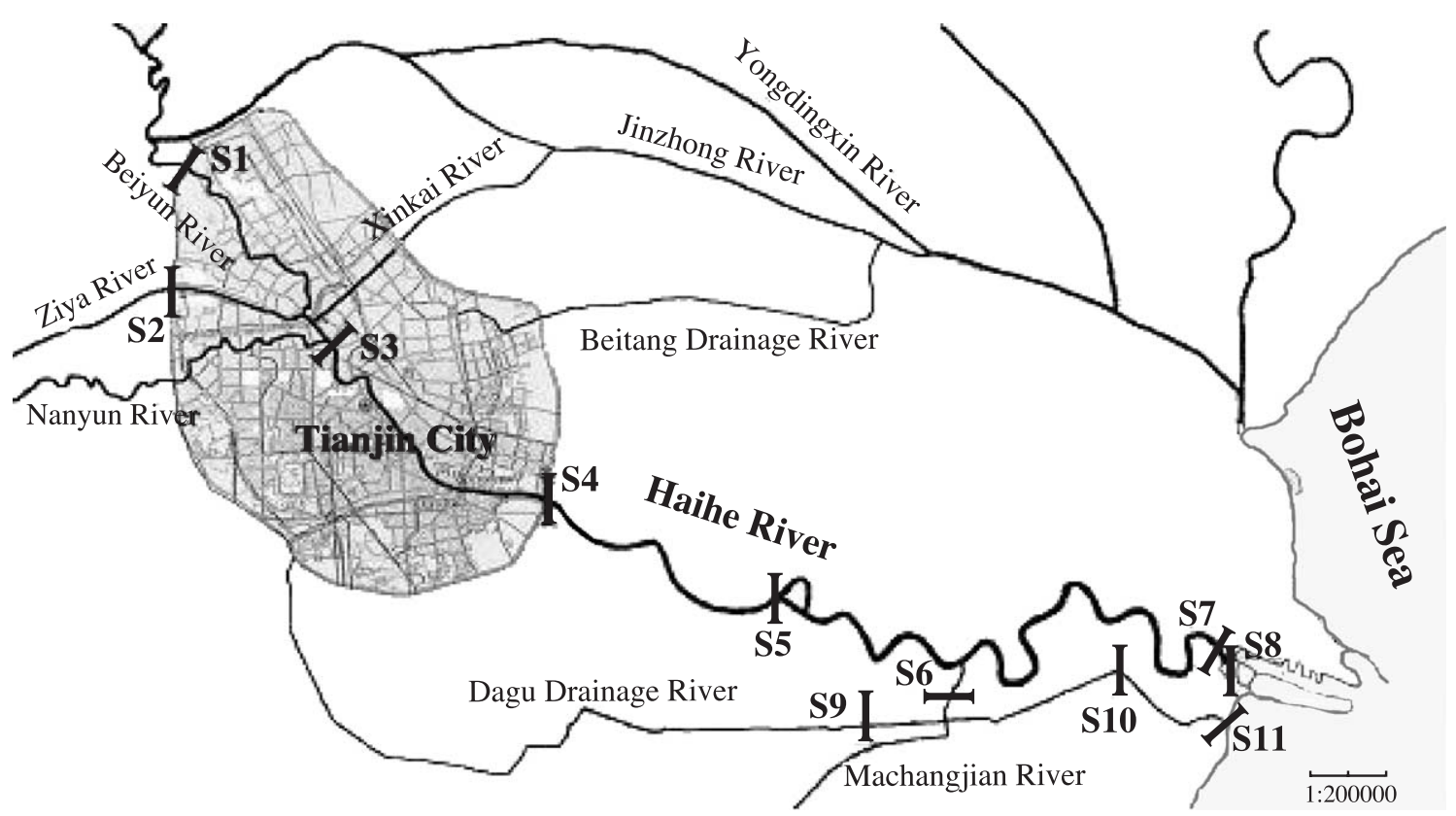

Fig. 1. The map of the study area. 
The HPLC mobile phase was prepared by pipetting 10 $\mathrm{mL} \mathrm{CH}{ }_{3} \mathrm{CN}, 25 \mu \mathrm{L}$ 2-Mercaptoethanol (Merck) and $10 \mathrm{~mL}$ $3 \mathrm{~mol} \mathrm{~L}^{-1} \mathrm{NH}_{4} \mathrm{Ac}$ solutions to Milli-Q water to $500 \mathrm{~mL}$, then filtered through a $0.45-\mu \mathrm{m}$ membrane filter before use.

Bromine monochloride $(\mathrm{BrCl})$ should be prepared in a fume hood. Twenty-seven grams of $\mathrm{KBr}$ crystals were added to a 2.5 -L bottle of low $\mathrm{Hg}$ concentrated $\mathrm{HCl}$. Using a clean magnetic stir bar, the contents were stirred $1 \mathrm{~h}$. Then, $38 \mathrm{~g}$ of $\mathrm{KBrO}_{3}$ were added slowly to the acid mixture while stirring. When all of the $\mathrm{KBrO}_{3}$ is added, the solution should change from yellow to red to orange. The bottle was loosely capped, and the solution was stirred for another hour before tightening the lid.

$\mathrm{KBH}_{4}$ solutions $(0.2 \%, \mathrm{~m} / \mathrm{v})$ were prepared before use by dissolving the required amount in $0.2 \%(\mathrm{~m} / \mathrm{v}) \mathrm{KOH}$ solution. An oxidant solution of $1 \%(\mathrm{~m} / \mathrm{v}) \mathrm{K}_{2} \mathrm{~S}_{2} \mathrm{O}_{8}$ solution was prepared in $10 \%(\mathrm{v} / \mathrm{v}) \mathrm{HCl}$. The mixture solution containing $0.1 \mathrm{~mol} \mathrm{~L}^{-1} \mathrm{CH}_{3} \mathrm{COOH}$ and $0.01 \mathrm{~mol} \mathrm{~L}^{-1} \mathrm{HCl}$ was obtained by diluting $6 \mathrm{~mL}$ of glacial acetic acid and 0.8 $\mathrm{mL}$ of concentrated $\mathrm{HCl}$ to $1 \mathrm{~L}$ with Milli-Q water. $\mathrm{KOH}$ solution $\left(1 \mathrm{~mol} \mathrm{~L}^{-1}\right)$ and $\mathrm{HNO}_{3}$ solution $\left(12 \mathrm{~mol} \mathrm{~L}^{-1}\right)$ were also used in this work.

\subsection{Sample collection}

A total of 21 sediment samples in 11 sites along the Haihe River and Dagu Drainage River was collected on July $12-13$ and Sept. 6-7, 2003, respectively. The map of study area and the locations of sampling sites are shown in Fig. 1. S1 and S2 locate in two headstreams of Haihe River (Beiyun River and Ziya River) and upriver to Tianjin city. They were chosen to judge if the river has been polluted before flowing through Tianjin city. Xinkai River and Nanyun River are two streamlets outflowing from Haihe River and no sediments were sampled. S3, which lies in urban district, is an important intersection point of branches with Haihe River. However, the sediment was not obtained from there on July $12-13$. S4 is the locus where Haihe River flows out to Tianjin city. S5 and S7 are two brakes in Haihe River and they control the flux of water in Haihe River. The water of Machangjian River inpour into Haihe River and S6 was selected there. As a contrast, three sites (S9, S10 and S11) in Dagu Drainage River were also sampled because this river is an important drainage river in Tianjin city and very near to Haihe River.

All the sediments were collected with a stainless steel grab from the surface sediment $(0-5 \mathrm{~cm})$, then placed into polytetrafluoroethylene (PTFE) bags, frozen at $-20{ }^{\circ} \mathrm{C}$ immediately after the collection. Because vacuum drying was often suggested for drying of some certified reference materials (CRMs; such as DORM-2 and TORT-2) and freeze drying has been used in preparation of CRM IAEA142 (Horvat et al., 1997), the sediments collected from Haihe River and Dagu Drainage River were freeze dried, ground and passed through a 40-mesh sieve, then thoroughly homogenized and kept in a silica gel desiccator until analyzing.

\subsection{Procedures}

For total mercury (HgT) analysis, $0.25 \mathrm{~g}$ of sediment was weighed in a $25-\mathrm{mL}$ graduated tube and $5 \mathrm{~mL}$ Milli$\mathrm{Q}$ water and $5 \mathrm{~mL}$ aqua regia were added. The mixture in the tube was then heated $2 \mathrm{~h}$ with a water bath at $95{ }^{\circ} \mathrm{C}$ and shaken frequently. After cooling, the content was diluted to $25 \mathrm{~mL}$ with Milli-Q water. The $\mathrm{HgT}$ can be determined by CVAFS directly when the solution was limpid.

Table 1

Scheme for the sequence extraction of mercury in sediment

\begin{tabular}{|c|c|c|}
\hline Step & Extraction method & Fraction of $\mathrm{Hg}$ \\
\hline 1 & $\begin{array}{l}\text { Two grams of sediments were weighed } \\
\text { into a } 50 \text {-mL glass centrifuge tube and } \\
20 \mathrm{~mL} \text { of Milli-Q water was added. } \\
\text { The tube was vibrated for } 18 \mathrm{~h} \text { at room } \\
\text { temperature, and then centrifuged. } \\
\text { An exactly known volume of the } \\
\text { extraction }(8 \mathrm{~mL}) \text { was filtered and } \\
\text { transferred into a } 10-\mathrm{mL} \text { tube. One } \\
\text { milliliter of concentrated } \mathrm{HNO}_{3} \text { and } 0.1 \\
\mathrm{~mL} \text { of } \mathrm{BrCl} \text { were added. The volume } \\
\text { was then made up to } 10 \mathrm{~mL} \text { by adding } \\
\text { in Milli-Q water. The residue was } \\
\text { washed with } 20 \mathrm{~mL} \text { water by shaking }\end{array}$ & $\begin{array}{l}\text { Water soluble } \\
(\mathrm{Hg}-\mathrm{w})\end{array}$ \\
\hline
\end{tabular}
for $15 \mathrm{~min}$, centrifuged, and the rinse was discarded.

2 The residue was extracted with $20 \mathrm{~mL}$ of $0.1 \mathrm{~mol} \mathrm{~L}^{-1} \mathrm{CH}_{3} \mathrm{COOH}+0.01$ mol L ${ }^{-1} \mathrm{HCl}$ solution and then rinsed with another $20 \mathrm{~mL}$ solution. The detailed operation conditions were the same as those of step 1.

3 The residue was extracted with $20 \mathrm{~mL}$ of $1 \mathrm{~mol} \mathrm{~L}^{-1} \mathrm{KOH}$ solution and then rinsed with another $20 \mathrm{~mL}$ solution. The detailed operation conditions were the same as those of step 1. Because the solution has high acid neutralizing capacity, more concentrated $\mathrm{HNO}_{3}$ $(1.5 \mathrm{~mL})$ should be added.

4 The residue was extracted with $20 \mathrm{~mL} \quad$ Elemental $\mathrm{Hg}$ of $12 \mathrm{~mol} \mathrm{~L}^{-1} \mathrm{HNO}_{3}$ solution and then (Hg-e) rinsed with another $20 \mathrm{~mL}$ solution. The detailed operation conditions were the same as those of step 1 . When determining the total $\mathrm{Hg}$ in this fraction, a series of mercury standard solutions in $12 \mathrm{~mol} \mathrm{~L}^{-1} \mathrm{HNO}_{3}$ were used.

5 The residue was air dried at room temperature, and the total $\mathrm{Hg}$ was

'Human stomach acid' soluble (Hg-h)

Organo-chelated (Hg-o) digested with aqua regia and determined by CVAFS. The procedure was the same as those of determination of total $\mathrm{Hg}$ in sediment. 
The determination of methylmercury in sediments was based on acid extraction (Wilken and Hintelmann, 1991; Hintelmann et al., 1997) and HPLC-CVAFS technique published previously (Liang et al., 2003a) with the following modifications. Ten grams of sediment were weighed into a $250-\mathrm{mL}$ flask and $50 \mathrm{~mL}$ of $6 \mathrm{~mol} \mathrm{~L}^{-1} \mathrm{HCl}$ solution was added. The flask was mechanically shaken overnight, and then $25 \mathrm{~mL} \mathrm{CH}_{2} \mathrm{Cl}_{2}$ was added and shaken for another $2 \mathrm{~h}$ to extract organic mercury into the $\mathrm{CH}_{2} \mathrm{Cl}_{2}$ phase. After centrifugation, the $\mathrm{CH}_{2} \mathrm{Cl}_{2}$ phase was transferred into a 25 $\mathrm{mL}$ graduated tube and concentrated to $4 \mathrm{~mL}$ with a gentle stream of pure nitrogen. Then, the solution was extracted with $1 \mathrm{~mL} 0.01 \mathrm{~mol} \mathrm{~L}^{-1}$ sodium thiosulfate. Shaking $45 \mathrm{~min}$ was needed to hasten the extraction speed. After setting for a few minutes for phase separation, the water phase was removed by micropipette and transferred into a clean 1-ml screw cap glass vial. The MeHg was determined by HPLCCVAFS at optimized conditions.

The sequential extraction procedure was based on Bloom's five-step sequential extraction scheme (Bloom et al., 2003), which is summarized in Table 1. The total Hg in each fraction was determined by CVAFS after oxidation with $\mathrm{BrCl}$, since $\mathrm{BrCl}$ has been found to be an excellent oxidant and preservative for total $\mathrm{Hg}$ in water samples (Bloom and Crecelius, 1983) and adopted in EPA method 1631.

\section{Results and discussion}

\subsection{Evaluation of the methods}

For HgT determination, the method was verified by analysis of two certified reference materials (sediment GBW07310 for $\mathrm{HgT}, 280 \pm 40 \mathrm{ng} \mathrm{g}^{-1}$ and soil GBW08302 for $\mathrm{HgT}, 18 \mathrm{ng} \mathrm{g}^{-1}$ ). Our results for $\mathrm{HgT}$ were $275 \pm 11 \mathrm{ng} \mathrm{g}^{-1}(n=5)$ in GBW07310 and $22 \pm 4 \mathrm{ng}$ $\mathrm{g}^{-1}(n=5)$ in GBW08302, respectively. The HPLCCVAFS system was validated with certified reference material DORM-2 (Dogfish muscle) and the result was in good agreement with the certified values (Liang et al., 2003a). Due to lack of sediment certified reference materials (CRMs) for $\mathrm{MeHg}$ in our laboratory, 10 and $100 \mu \mathrm{L}$ of $1 \mu \mathrm{g} \mathrm{mL}^{-1} \mathrm{MeHg}$ standard solutions were respectively added into sediments of S5 and S11 collected on July $12-13$. The spiked recoveries of $\mathrm{MeHg}$ were between $80 \%$ and $96 \%$. For sequential selective extraction, sediment certified reference material GBW07310 was also determined and the recovery of $\mathrm{Hg}\left(\sum \mathrm{Hg} / \mathrm{HgT}\right)$ was $89 \%$. The contents and percentages of $\mathrm{Hg}$ in each fraction were shown in Tables 2 and 3, respectively. For other samples, the ratios of $\mathrm{\sum Hg}$ to $\mathrm{HgT}$ ranged from $76 \%$ to $117 \%$ (Table 2), which indicated that the method was reliable and repeatable.

Table 2

The Hg contents in each fraction of sediments (ng $\mathrm{g}^{-1}$, dry weight)

\begin{tabular}{|c|c|c|c|c|c|c|c|}
\hline Sampling sites & $\mathrm{Hg}-\mathrm{w}$ & $\mathrm{Hg}-\mathrm{h}$ & $\mathrm{Hg}-\mathrm{O}$ & $\mathrm{Hg}-\mathrm{e}$ & $\mathrm{Hg}-\mathrm{s}$ & $\sum H g$ & $\sum_{(\%)} \mathrm{Hg} / \mathrm{HgT}$ \\
\hline GBW07310 & 1.6 & 0.8 & 66.6 & 60.6 & 120.6 & 250.1 & 89 \\
\hline \multicolumn{8}{|l|}{ July 12-13 } \\
\hline $\mathrm{S} 1$ & 0.8 & 0.5 & 22.9 & 37.8 & 54.2 & 116.2 & 102 \\
\hline $\mathrm{S} 2$ & 0.3 & $\mathrm{ND}^{\mathrm{a}}$ & 10.1 & 31.7 & 19.1 & 61.1 & 101 \\
\hline S4 & 2.4 & 0.6 & 29.3 & 67.6 & 76.5 & 176.4 & 101 \\
\hline S5 & 0.8 & 0.6 & 11.2 & 63.1 & 50.6 & 126.3 & 89 \\
\hline S6 & 0.8 & ND & 4.8 & 40.6 & 43.5 & 89.7 & 80 \\
\hline S7 & 0.7 & ND & 14.6 & 53.9 & 34.8 & 104.0 & 104 \\
\hline S8 & 0.6 & ND & 16.4 & 122.1 & 49.7 & 188.7 & 89 \\
\hline S9 & 1.1 & 8.3 & 287.5 & 1425.7 & 552.7 & 2275.3 & 100 \\
\hline S10 & 2.1 & 6.4 & 288.9 & 723.0 & 412.5 & 1432.9 & 82 \\
\hline S11 & 1.2 & 2.5 & 59.2 & 422.3 & 308.6 & 793.8 & 79 \\
\hline \multicolumn{8}{|l|}{ Sept. 6-7 } \\
\hline $\mathrm{S} 1$ & 1.2 & 1.3 & 13.0 & 21.7 & 32.4 & 69.6 & 117 \\
\hline $\mathrm{S} 2$ & 0.3 & 1.8 & 14.1 & 19.1 & 29.5 & 64.9 & 117 \\
\hline $\mathrm{S} 3$ & 0.1 & 1.5 & 33.0 & 431.8 & 1357.3 & 1823.6 & 84 \\
\hline S4 & 0.6 & 0.1 & 27.8 & 48.1 & 57.9 & 134.5 & 103 \\
\hline S5 & 1.3 & 1.7 & 17.0 & 58.2 & 54.6 & 132.8 & 103 \\
\hline S6 & ND & 5.0 & 12.1 & 27.4 & 63.5 & 108.1 & 79 \\
\hline S7 & 1.0 & 0.7 & 8.3 & 73.2 & 56.9 & 140.0 & 97 \\
\hline S8 & 0.7 & 0.6 & 35.6 & 98.7 & 61.6 & 197.1 & 81 \\
\hline S9 & 4.4 & 0.8 & 644.0 & 4370.2 & 1621.5 & 6640.9 & 76 \\
\hline S10 & 2.0 & 4.6 & 467.0 & 1679.4 & 732.6 & 2885.6 & 85 \\
\hline S11 & 1.2 & 0.1 & 60.2 & 272.7 & 116.5 & 450.6 & 77 \\
\hline
\end{tabular}

${ }^{a}$ Not detectable. 
Table 3

Percentages of $\mathrm{Hg}$ in each fraction of sediments (\%)

\begin{tabular}{|c|c|c|c|c|c|}
\hline Sampling sites & $\mathrm{Hg}-\mathrm{w}$ & Hg-h & $\mathrm{Hg}-\mathrm{O}$ & Hg-e & $\mathrm{Hg}-\mathrm{s}$ \\
\hline GBW07310 & 0.6 & 0.3 & 26.6 & 24.2 & 48.2 \\
\hline \multicolumn{6}{|l|}{ July 12-13 } \\
\hline $\mathrm{S} 1$ & 0.7 & 0.4 & 19.7 & 32.5 & 46.6 \\
\hline $\mathrm{S} 2$ & 0.5 & $\mathrm{ND}^{\mathrm{a}}$ & 16.5 & 51.9 & 31.3 \\
\hline S4 & 1.4 & 0.3 & 16.6 & 38.3 & 43.4 \\
\hline S5 & 0.6 & 0.5 & 8.9 & 50.0 & 40.1 \\
\hline S6 & 0.9 & ND & 5.4 & 45.3 & 48.5 \\
\hline S7 & 0.7 & ND & 14.0 & 51.8 & 33.5 \\
\hline S8 & 0.3 & ND & 8.7 & 64.7 & 26.3 \\
\hline S9 & ND & 0.4 & 12.6 & 62.7 & 24.3 \\
\hline $\mathrm{S} 10$ & 0.1 & 0.4 & 20.2 & 50.5 & 28.8 \\
\hline $\mathrm{S} 11$ & 0.2 & 0.3 & 7.5 & 53.2 & 38.9 \\
\hline \multicolumn{6}{|l|}{ Sept. 6-7 } \\
\hline $\mathrm{S} 1$ & 1.7 & 1.9 & 18.7 & 31.2 & 46.6 \\
\hline $\mathrm{S} 2$ & 0.5 & 2.8 & 21.7 & 29.4 & 45.5 \\
\hline $\mathrm{S} 3$ & ND & 0.1 & 1.8 & 23.7 & 74.4 \\
\hline S4 & 0.4 & 0.1 & 20.7 & 35.8 & 43.0 \\
\hline S5 & 1.0 & 1.3 & 12.8 & 43.8 & 41.1 \\
\hline S6 & ND & 4.6 & 11.2 & 25.3 & 58.7 \\
\hline S7 & 0.7 & 0.5 & 5.9 & 52.3 & 40.6 \\
\hline S8 & 0.4 & 0.3 & 18.1 & 50.1 & 31.3 \\
\hline S9 & 0.1 & ND & 9.7 & 65.8 & 24.4 \\
\hline S10 & 0.1 & 0.2 & 16.2 & 58.2 & 25.4 \\
\hline S11 & 0.3 & ND & 13.4 & 60.5 & 25.9 \\
\hline
\end{tabular}

${ }^{\mathrm{a}}$ Not detectable.

\subsection{Total mercury and methylmercury in sediments}

The concentrations of $\mathrm{HgT}$ and $\mathrm{MeHg}$ in Haihe River and Dagu Drainage River sediments are presented in Table 4. Although the lowest $\mathrm{HgT}$ content in sediment was $55.4 \mathrm{ng}$ $\mathrm{g}^{-1}$ (dry weight), the average value reached $1036.5 \mathrm{ng} \mathrm{g}^{-1}$ (dry weight). This was mainly because the sediments collected from four sites (S3, S9, S10 and S11) had unusually high $\mathrm{HgT}$ contents and the maximum value was $8779.1 \mathrm{ng} \mathrm{g}^{-1}$ (dry weight). The distribution of $\mathrm{HgT}$ in Haihe River and Dagu Drainage River sediments is depicted in Fig. 2. Craig (1986) reported concentration ranges of 0.2 to $0.4 \mu \mathrm{g} \mathrm{g}^{-1}$ total $\mathrm{Hg}$ for uncontaminated sediments, whereas sediments in urban, industrial or mineralized areas can contain up to $100 \mu \mathrm{g} \mathrm{g}^{-1}$ total Hg. Fujii (1976) reported background levels of $0.05 \mu \mathrm{g} \mathrm{g}^{-1}$ in river sediments, 0.1 to $0.3 \mu \mathrm{g} \mathrm{g}^{-1}$ in lake sediments and 0.05 to $0.08 \mu \mathrm{g} \mathrm{g}^{-1}$ in sea sediments. Therefore, the $\mathrm{HgT}$ contents in sediments collected from S1 and S2 (between 55.4 and $113.7 \mathrm{ng}$ $\mathrm{g}^{-1}$, dry weight) were only a little higher than the background values reported and within the ranges for uncontaminated sediments; thus, these two sites could be considered as uncontaminated. From S4 to S8, the $\mathrm{HgT}$ contents in sediments were slightly higher than those in sediments of S1 and S2, which ranged from 99.9 to $242.0 \mathrm{ng}$ $\mathrm{g}^{-1}$ (dry weight). In contrast to these, unexpected high mercury concentration (2172.6 $\mathrm{ng} \mathrm{g}^{-1}$ dry weight) was found in sediment collected from S3, which is located in urban district. Therefore, we can conclude that the Haihe
River was not polluted before entering into Tianjin city (S1 and S2). At the location of S3, the river was polluted seriously with $\mathrm{Hg}$. We speculated that there were unknown pollution sources of $\mathrm{Hg}$ near to S3, which still need to be confirmed by further study in the future. However, the downstream areas (from S4 to S8) of S3 were just slightly polluted, probably because of the dilution of river water. Moreover, apart from these sites located in suburban areas of Tianjin city and a few factories built there, there were no other pollution sources of $\mathrm{Hg}$ in these areas (including S6). On the contrary, the sediments collected from Dagu Drainage River (S9-S11), an important drainage river in Tianjin city, were found to have very high $\mathrm{Hg}$ concentrations and the highest concentration reached $8779.1 \mathrm{ng} \mathrm{g}^{-1}$ (dry weight). Hence, Dagu Drainage River has been polluted seriously with $\mathrm{Hg}$, which also meant that the amount of $\mathrm{Hg}$ discharged from Tianjin industrial effluents was enormous. Because these effluents were poured into Bohai Sea directly, the Hg levels in fish and mollusk samples collected from this area of Bohai Sea are always high (Tan et al., 1982; Zhang and Chen, 1984; Liang et al., 2003b).

The MeHg contents in sediments account for normally $1 \%$ to $1.5 \%$ of $\mathrm{HgT}$ except for some lakes and wetlands where the percentage of $\mathrm{MeHg}$ can reach $10 \%$ (Gilmour et al., 1992; Ullrich et al., 2001). In Haihe River and Dagu Drainage River sediments, the $\mathrm{MeHg}$ concentrations ranged from 0.7 to $21.7 \mathrm{ng} \mathrm{g}^{-1}$ (dry weight) and the average value was $2.9 \mathrm{ng} \mathrm{g}^{-1}$ (dry weight). The percentages of MeHg in HgT were between $0.1 \%$ and $2.4 \%$ and the average was

Table 4

Concentrations of HgT, MeHg and TOC in Haihe River and Dagu Drainage River sediments (dry weight)

\begin{tabular}{|c|c|c|c|c|}
\hline Sampling sites & $\begin{array}{l}\mathrm{HgT} \\
\left(\mathrm{ng} \mathrm{g}^{-1}\right)\end{array}$ & $\begin{array}{l}\mathrm{MeHg} \\
\left(\mathrm{ng} \mathrm{g}^{-1}\right)\end{array}$ & $\begin{array}{l}\mathrm{MeHg} / \mathrm{HgT} \\
(\%)\end{array}$ & $\begin{array}{l}\text { TOC } \\
\left(\mathrm{mg} \mathrm{g}^{-1}\right)\end{array}$ \\
\hline \multicolumn{5}{|l|}{ July 12-13 } \\
\hline $\mathrm{S} 1$ & 113.7 & 1.0 & 0.9 & 8.20 \\
\hline $\mathrm{S} 2$ & 60.8 & 1.4 & 2.2 & 9.08 \\
\hline S4 & 174.4 & 0.7 & 0.4 & 12.40 \\
\hline S5 & 142.5 & 0.7 & 0.5 & 15.65 \\
\hline S6 & 111.7 & 1.1 & 1.0 & 10.54 \\
\hline S7 & 99.9 & 1.0 & 1.0 & 6.41 \\
\hline S8 & 211.2 & 1.7 & 0.8 & 4.15 \\
\hline S9 & 2279.5 & 1.2 & 0.1 & 58.63 \\
\hline $\mathrm{S} 10$ & 1750.1 & 3.9 & 0.2 & 33.00 \\
\hline S11 & 1001.0 & 21.7 & 2.2 & 5.47 \\
\hline \multicolumn{5}{|l|}{ Sept. 6-7 } \\
\hline S1 & 59.4 & 1.5 & 2.4 & 5.44 \\
\hline $\mathrm{S} 2$ & 55.4 & 1.4 & 2.4 & 6.52 \\
\hline S3 & 2172.6 & 3.4 & 0.2 & 22.40 \\
\hline S4 & 131.2 & 0.8 & 0.6 & 7.30 \\
\hline S5 & 128.5 & 1.4 & 1.1 & 33.16 \\
\hline S6 & 137.6 & 0.9 & 0.7 & 8.54 \\
\hline S7 & 144.4 & 0.9 & 0.6 & 4.18 \\
\hline S8 & 242.0 & 1.3 & 0.5 & 4.66 \\
\hline S9 & 8779.1 & 7.7 & 0.1 & 80.20 \\
\hline $\mathrm{S} 10$ & 3389.6 & 5.2 & 0.2 & 45.66 \\
\hline S11 & 582.4 & 2.3 & 0.4 & 4.58 \\
\hline
\end{tabular}




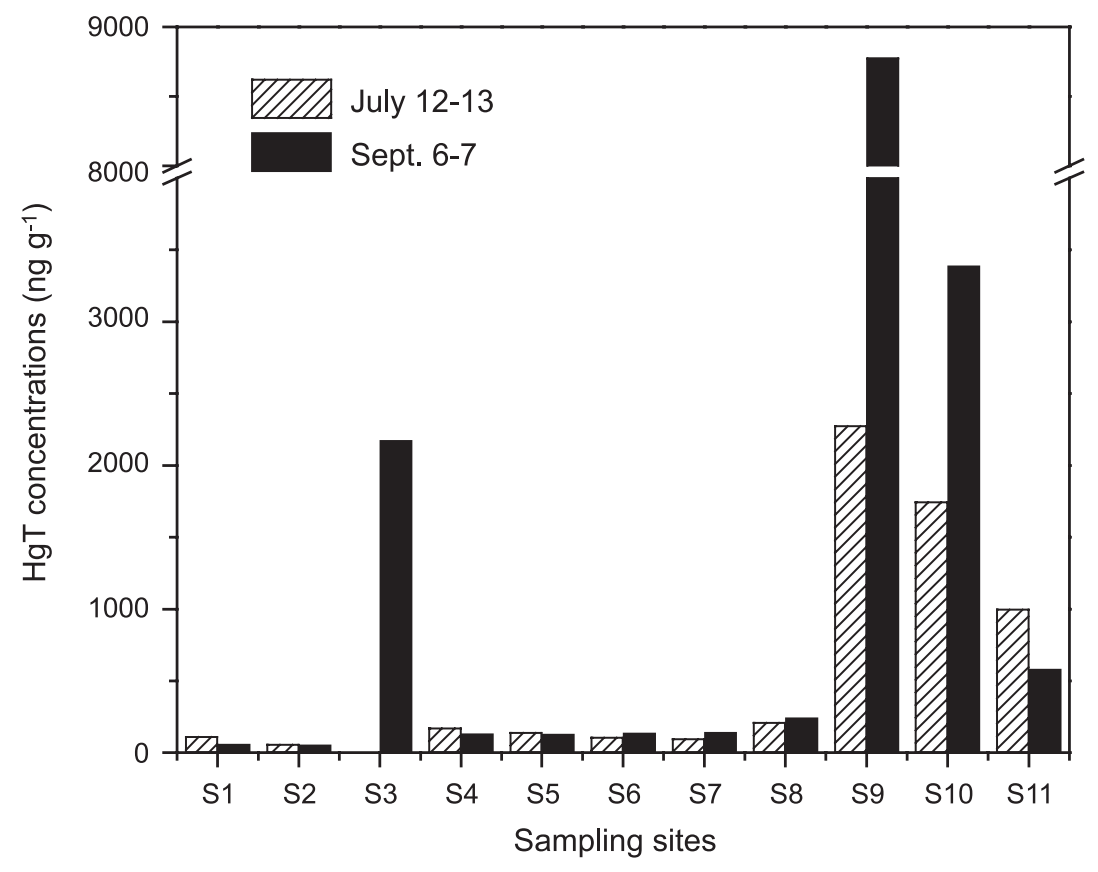

Fig. 2. The distribution of total Hg in Haihe River and Dagu Drainage River sediments.

$0.9 \%$. The distribution of $\mathrm{MeHg}$ in sediments is shown in Fig. 3. The concentration of $\mathrm{MeHg}\left(21.7 \mathrm{ng} \mathrm{g}^{-1}\right.$, dry weight) in sediment of S11 collected on July $12-13$ was much higher than that in other sediments, although its percentage was only $2.2 \%$. Except for this abnormally high $\mathrm{MeHg}$ concentration, the distribution of $\mathrm{MeHg}$ in Haihe River and Dagu Drainage River sediments was similar to that of HgT. The relationship between $\mathrm{MeHg}$ and $\mathrm{HgT}$ was then studied and $\mathrm{MeHg}$ showed a significant correlation
( $r=0.91, p=0.99, n=20$; Fig. 4) with $\mathrm{HgT}$ when $\mathrm{MeHg}$ in sediment of S11 was excluded. This suggested that $\mathrm{MeHg}$ contents were partly controlled by the $\mathrm{HgT}$ in sediments.

Organic carbon plays an important role in the bioavailability and methylation of inorganic mercury, although its role has not been well understood (Andersson et al., 1990). Ullrich et al. (2001) argued that, on the one hand, organic carbon can enhance methylation by stimulating the activity of heterotrophic microorganisms, or through direct abiotic

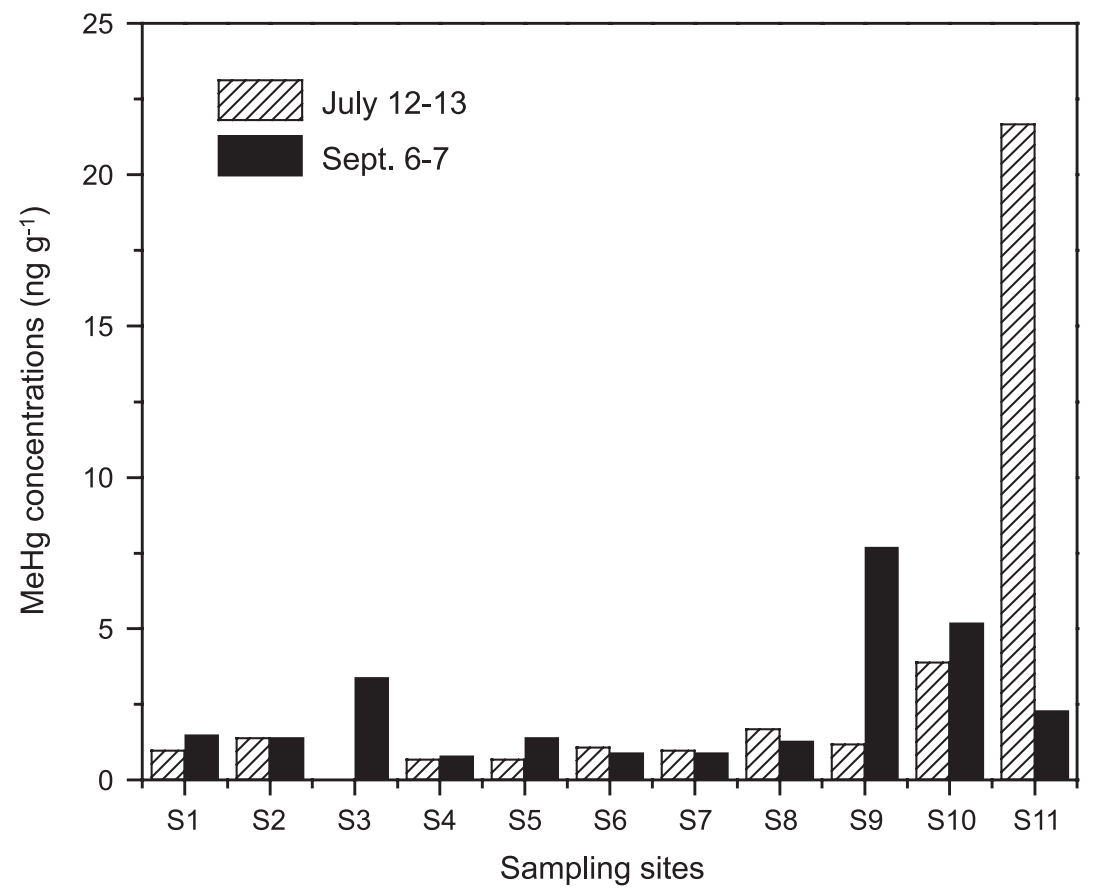

Fig. 3. The distribution of MeHg in Haihe River and Dagu Drainage River sediments. 


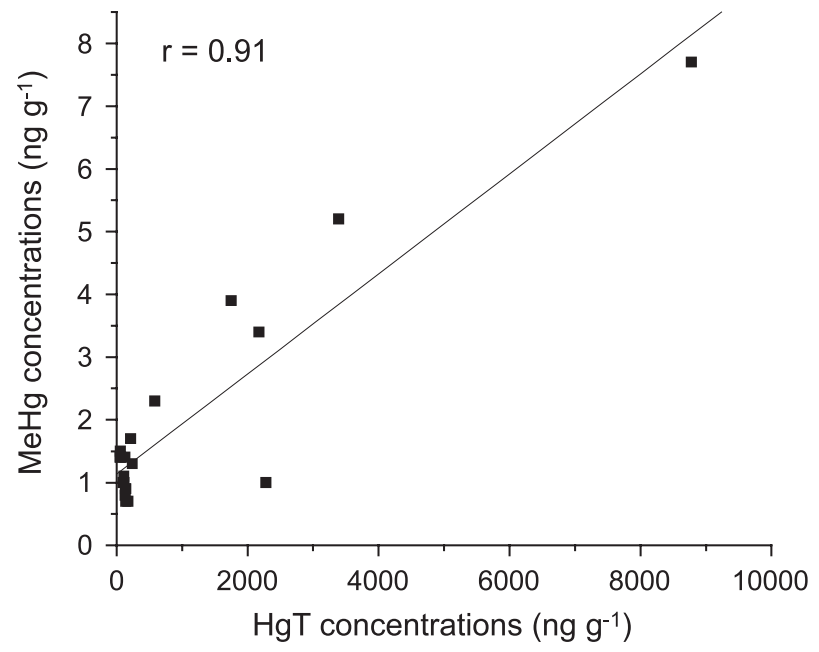

Fig. 4. The relationship between $\mathrm{HgT}$ and $\mathrm{MeHg}$ concentrations.

methylation of $\mathrm{Hg}$ by humic or fulvic substances. On the other hand, $\mathrm{Hg}$ methylation may be inhibited at high DOC concentrations due to increased complexation of $\mathrm{Hg}$ with organic ligands, reducing $\mathrm{Hg}$ bioavailability to bacterias, particularly in the neutral $\mathrm{pH}$ range. The TOC concentrations in Haihe River and Dagu Drainage River sediments were also investigated. The contents of TOC in sediments varied from 4.15 to $80.20 \mathrm{mg} \mathrm{g}^{-1}$ (average: $18.39 \mathrm{mg} \mathrm{g}^{-1}$ ). The HgT concentrations $(r=0.87, p=0.99, n=21$; Fig. 5a) and $\mathrm{MeHg}$ concentrations $(r=0.76, p=0.99, n=20$; Fig. $5 \mathrm{~b})$ were significantly correlated with TOC contents except the very high $\mathrm{MeHg}$ content, which indicates that the concentrations of $\mathrm{HgT}$ and $\mathrm{MeHg}$ in sediments of Haihe River and Dagu Drainage River were partly influenced by TOC contents in them. This result was in agreement with other studies (Conaway et al., 2003; Furutani and Rudd, 1980; Olson and Cooper, 1976).

\subsection{The mobility and bioavailability of $\mathrm{Hg}$ in sediments}

Sequential selective extractions (SSEs) method has been used widely for understanding element distribution in the solid phase. However, the traditional sequential extraction procedures are commonly used to study relatively "typical" transition metals (such as $\mathrm{Cu}, \mathrm{Ni}, \mathrm{Co}$ and $\mathrm{Zn}$ ) and are not appropriate for mercury study (Wallschläger et al., 1998). Although some mercury-specific methods have been developed (Wallschläger et al., 1998; Revis et al., 1989a,b), the results on ambient samples are often contradictory. Recently, Bloom et al. (2003) developed and validated a new solid phase analytical scheme based upon selective extractions. Instead of species-specific information, this method provides differentiation of $\mathrm{Hg}$ compounds into behavioral classes. Hence, some traditional extractants used in SSEs, such as $\mathrm{CH}_{3} \mathrm{COOH}, \mathrm{NH}_{2} \mathrm{OH} \cdot \mathrm{HCl}$ and $\mathrm{H}_{2} \mathrm{O}_{2}$, etc., were not adopted. In this new procedure, water, $0.1 \mathrm{~mol} \mathrm{~L}^{-1}$ $\mathrm{CH}_{3} \mathrm{COOH}+0.01 \mathrm{~mol} \mathrm{~L}^{-1} \mathrm{HCl}$ solution, $1 \mathrm{~mol} \mathrm{~L}^{-1} \mathrm{KOH}$, $12 \mathrm{~mol} \mathrm{~L}^{-1} \mathrm{HNO}_{3}$ and aqua regia were sequentially used to extract $\mathrm{Hg}$ in sediment and the extracted $\mathrm{Hg}$ were defined as water soluble $\mathrm{Hg}(\mathrm{Hg}-\mathrm{w})$, 'human stomach acid' soluble $\mathrm{Hg}$ (Hg-h), organo-chelated $\mathrm{Hg}$ (Hg-o), elemental Hg (Hg-e) and mercuric sulfide ( $\mathrm{Hg}-\mathrm{s})$, respectively.

The above mentioned sequential extraction method was applied to analyze the Hg species in Haihe River and Dagu Drainage River sediments. Tables 2 and 3 give the concentrations and percentages of $\mathrm{Hg}$ in each fraction. Although these data are limited to describe the exactly binding states of $\mathrm{Hg}$ in sediments, they can provide some useful information about the mobility and bioavailability of $\mathrm{Hg}$ in sediments. As shown in Fig. 6, the Hg in Haihe River and Dagu Drainage River sediments exists mainly as Hg-e and $\mathrm{Hg}$-s, which account for $46.5 \%$ and $39.0 \%$ of $\mathrm{HgT}$, respectively. These two fractions of $\mathrm{Hg}$ have very low mobility and therefore can be thought of as unavailable species. Hg-o, accounting for $13.3 \%$ of $\mathrm{HgT}$, has the moderate mobility. On the contrary, Hg-w and Hg-h account for only $0.6 \%$ and $0.9 \%$ of $\mathrm{HgT}$ in sediments. However, they have the highest risk since they can easily enter the aquatic system and accumulate in organism. Therefore, $\mathrm{Hg}$ -
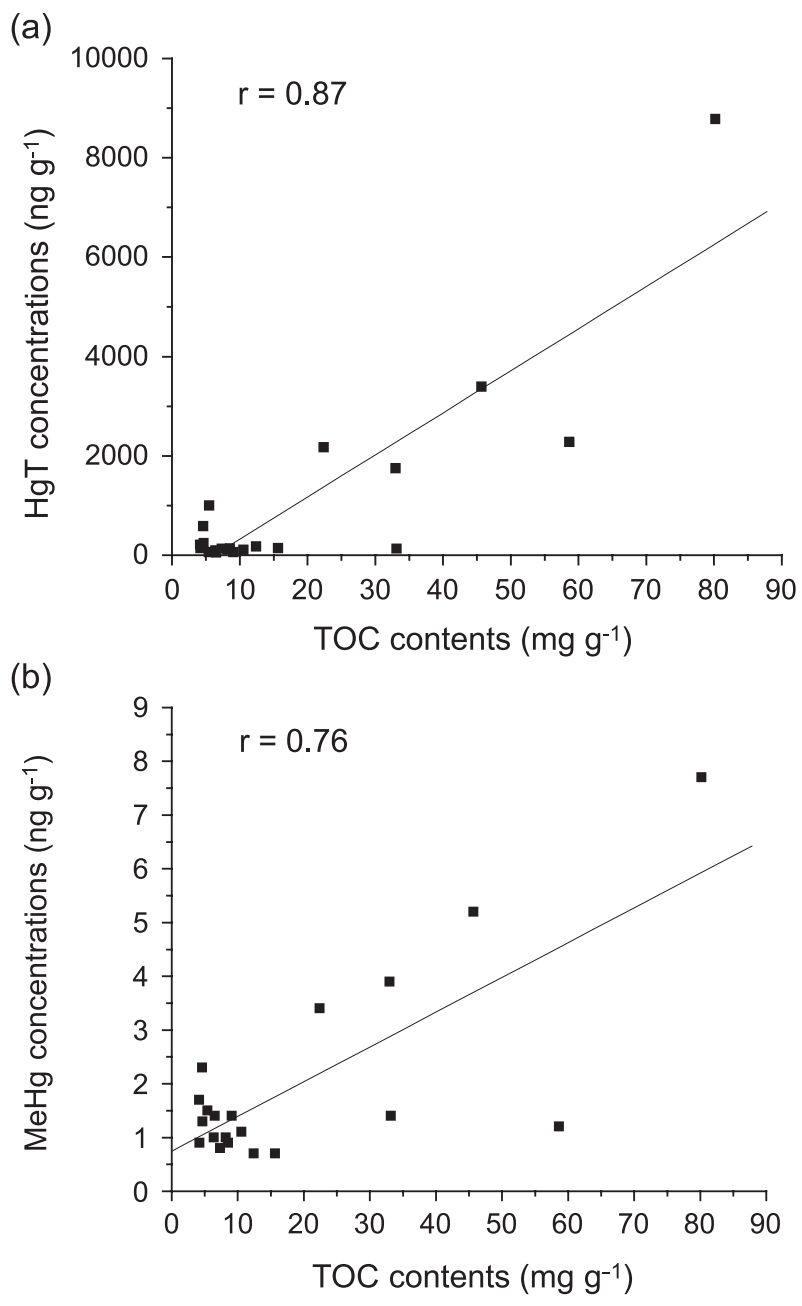

Fig. 5. The relationships between (a) TOC and HgT, and between (b) TOC and $\mathrm{MeHg}$. 


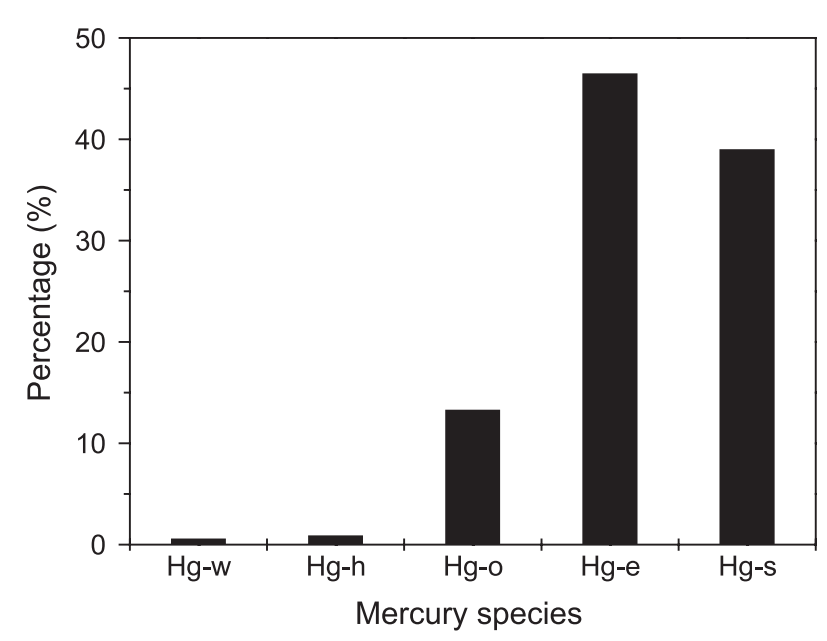

Fig. 6. The average percentages of $\mathrm{Hg}$ in each fraction.

w plus Hg-h was defined as exchangeable Hg in our work. The exchangeable $\mathrm{Hg}$ concentrations in Haihe River and Dagu Drainage River sediments ranged from 0.3 to $9.4 \mathrm{ng}$ $\mathrm{g}^{-1}$ (average: $2.9 \mathrm{ng} \mathrm{g}^{-1}$, dry weight), accounting for $0.1-$ 4.6\% (average: $1.1 \%$ ) of $\mathrm{HgT}$ in sediments. The distribution of exchangeable $\mathrm{Hg}$ in sediments was also studied (Fig. 7) and showed an obvious difference to that of HgT (Fig. 2). In sites 9,10 and 11 , the exchangeable $\mathrm{Hg}$ contents in sediments collected on July 12-13 were much higher than that in sediments collected on Sept. 6-7, which was opposite to the distribution of $\mathrm{HgT}$ in them. Furthermore, the exchangeable $\mathrm{Hg}$ in sediment of S6 collected on Sept. 67 reached $5.0 \mathrm{ng} \mathrm{g}^{-1}$ (dry weight), although the total $\mathrm{Hg}$ for which was only $137.6 \mathrm{ng} \mathrm{g}^{-1}$ (dry weight). Thus, the percentage of exchangeable $\mathrm{Hg}$ in this sediment was the maximum. All of these results confirmed that the total $\mathrm{Hg}$ concentrations were absolutely insufficient and it is indis- pensable to identify the main binding sites and phase associations of $\mathrm{Hg}$ when assessing its risk in sediment.

\section{Conclusions}

The pollution status and bioavailability of mercury in Haihe River and Dagu Drainage River sediments were studied. Although the Haihe River was just slightly polluted with $\mathrm{Hg}$ after flowing through Tianjin city, the HgT concentrations in Dagu Drainage River sediments were extraordinarily high, indicating that the amount of $\mathrm{Hg}$ discharged from Tianjin industrial effluents was still enormous. $\mathrm{MeHg}$ contents in sediments showed similar trend with $\mathrm{HgT}$ and were partly influenced by $\mathrm{HgT}$ and TOC contents. The sequential selective extraction method has proved to be a powerful technique to provide much useful information about the mobility and bioavailability of $\mathrm{Hg}$ in sediments. Although the exchangeable $\mathrm{Hg}$ accounted a low percent of $\mathrm{HgT}$, it ran the highest risk because it could easily enter into the aquatic system and accumulate in organism. Furthermore, the exchangeable $\mathrm{Hg}$ has a different variation with that of $\mathrm{HgT}$ contents in sediments, indicating that it is indispensable to identify the main binding sites and phase associations of $\mathrm{Hg}$ when assessing its risk in sediments.

\section{Acknowledgements}

This work was jointly supported by the National Basic Research Program of China (2003CB415001) and the National Natural Science Foundation of China (20137010 and 20205008).

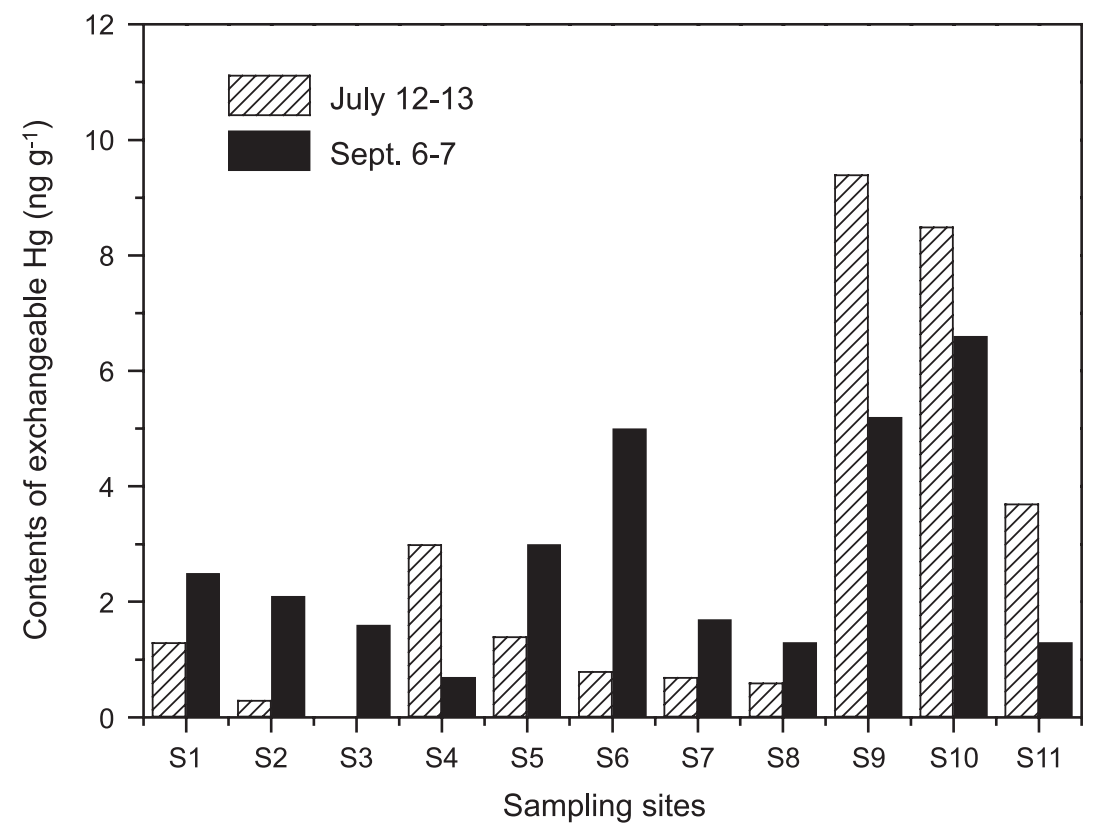

Fig. 7. The distribution of exchangeable Hg in Haihe River and Dagu Drainage River sediments. 


\section{References}

Andersson I, Parkman H, Jernelov A. The role of sediments as sink or source for environmental contamination: a case study of mercury and chlorinated organic compounds. Limnologica 1990;20:347-59.

Bloom NS, Crecelius EA. Determination of mercury in seawater at subnanogram per liter levels. Mar Chem 1983;14:49-59.

Bloom NS, Preus E, Katon J, Hiltner M. Selective extractions to assess the biogeochemically relevant fractionation of inorganic mercury in sediments and soils. Anal Chim Acta 2003;479:233-48.

Cai Y, Jaffé R, Jones R. Ethylmercury in the soils and sediments of the Florida Everglades. Environ Sci Technol 1997;31:302-5.

Conaway CH, Squire S, Mason RP, Flegal AR. Mercury speciation in the San Francisco Bay estuary. Mar Chem 2003;80:199-225.

Craig PJ. Organomercury compounds in the environment. Organometallic compounds in the environment: principles and reactions. Harlow: Longman; 1986. p. 65-110. Chap. 2.

Fujii M. Mercury distribution in lithosphere and atmosphere. In: Kitamura S, Kondo M, Takizawa Y, Fujii M, Fujiki M, editors. Mercury. Tokyo: Kodansha Scientific; 1976.

Furutani A, Rudd JWM. Measurement of mercury methylation in lake water and sediment samples. Appl Environ Microbiol 1980;40:770-6.

Gilmour CC, Henry EA, Mitchell R. Sulfate stimulation of mercury methylation in freshwater sediments. Environ Sci Technol 1992; 26:2281-7.

Hintelmann H, Welbourn PM, Evans RD. Binding of methylmercury compounds by humic and fulvic acid. Water Air Soil Pollut 1995;80:1031-4.

Hintelmann H, Falter R, Ilgen G, Evans RD. Determination of artifactual formation of monomethylmercury $\left(\mathrm{CH}_{3} \mathrm{Hg}^{+}\right)$in environmental samples using stable $\mathrm{Hg}^{2+}$ isotopes with ICP-MS detection: calculation of contents applying species specific isotope addition. Fresenius' J Anal Chem 1997;358:363-70.

Horvat M, Liang L, Azemard S, Mandić V, Villeneuve JP, Coquery M. Certification of total mercury and methylmercury concentrations in mussel homogenate (Mytilus edulis) reference material, IAEA-142. Fresenius' J Anal Chem 1997;358:411-8.

Liang LN, Jiang GB, Liu JF, Hu JT. Speciation analysis of mercury in seafood by using high-performance liquid chromatography on-line coupled with cold-vapor atomic fluorescence spectrometry via post column microwave digestion. Anal Chim Acta 2003a;477:131-7.

Liang LN, Shi JB, He B, Jiang GB. Investigation of methylmercury and total mercury contamination in mollusks samples collected from coastal sites along the Chinese Bohai Sea. J Agric Food Chem 2003b;51:7373-8.

Liu GH, Fu BJ, Yang P. Quality of aquatic environment at Haihe River and the pollutant fluxes flowing into sea. Chin J Environ Sci 2001;22:46-50.

Olson BH, Cooper RC. Comparison of aerobic and anaerobic methylation of mercuric chloride by San Francisco Bay sediments. Water Res 1976;10:113-6.

Qin BP, Zhai DH, Yuan Q, Zhang Y. Study on the aquatic ecosystem of Haihe River. Chin J Urban Environ Urban Ecol 1998;11(1):48-51.

Revis NW, Osborne TR, Sedgley D, King A. Quantitative method for determining the concentration of mercury(II) sulphide in soils and sediments. Analyst 1989;114:823-5.

Revis NW, Osborne TR, Holdsworth G, Hadden C. Quantitative method for determining the concentration of mercury(II) sulphide in soils and sediments. Analyst 1989;45:105-13.

Tan YX, Su HQ, Li XR, Wang TH. Use of Arca subcrenata as bio-indicator of mercury pollution in Bohai Bay. Chin J Environ Sci 1982;3:21-4.

Thayer JS. Organometallic compounds and living organisms. Orlando (FL): Academic Press; 1984.

Ullrich SM, Tanton TW, Abdrashltova SA. Mercury in the aquatic environment: a review of factors affecting methylation. Crit Rev Environ Sci Technol 2001;31:241-93.

Wallschläger D, Desai MVM, Wilken RD. The role of humic substances in the aqueous mobilization of mercury from contaminated floodplain soils. Water Air Soil Pollut 1996;90:507-20.

Wallschläger D, Desai MVM, Spengler M, Wilken RD. Mercury speciation in floodplain soils and sediments along a contaminated river transect. J Environ Qual 1998;27:1034-44.

Wilken RD, Hintelmann H. Mercury and methylmercury in sediments and suspended particles from the river Elbe, North Germany. Water Air Soil Pollut 1991;56:427-37.

Zhang, Q.X., Prevention and cure the water pollution in Tianjin city. http:// www.waterinfo.net.cn/. 2002

Zhang YQ, Chen XL. The accumulation and transformation of mercury in BoHai Bay ecosystem. Chin J Environ Sci 1984;5:27-30.

Zhao J, Wang DR, Cui SZ. Model analysis of dissolved oxygen in the water of Haihe River, Tianjin. Chin J Agro-Environ Prot 1996;15:29-31.

Zhen MZ, Qian XC, Cheng G, Lu DF. The environmental function and quality standard of surface water in Tianjin. Chin J Urban Environ Urban Ecol 1999;12(6):10-2. 